\title{
Immunohistochemical expression of MMP-7 protein and its serum level in colorectal cancer
}

\author{
Anna Pryczynicz', Mariusz Gryko², Katarzyna Niewiarowska', Violetta Dymicka-Piekarska², \\ Marek Ustymowicz ${ }^{4}$, Maciej Hawryluk¹, Dariusz Cepowicz², Agnieszka Borsuk², \\ Andrzej Kemona ${ }^{1}$, Waldemar Famulski ${ }^{5}$, Katarzyna Guzinska-Ustymowicz ${ }^{1}$
}

\author{
${ }^{1}$ Department of General Pathomorphology, Medical University of Bialystok, Bialystok, Poland \\ 22nd Department of General and Gastroenterological Surgery, Medical University of Bialystok, \\ Bialystok, Poland \\ ${ }^{3}$ Department of Clinical Laboratory Diagnostics, Medical University of Bialystok, Bialystok, Poland \\ ${ }^{4}$ Faculty of Computer Science, Bialystok University of Technology, Bialystok, Poland \\ ${ }^{5}$ Department of Medical Pathomorphology, Medical University of Bialystok, Bialystok, Poland
}

\begin{abstract}
The study objective was to determine the presence of MMP-7 in cancer tissue in correlation with its serum level in patients diagnosed with colorectal cancer (CRC). In 45 patients with CRC, MMP-7 expression was assessed immunohistochemically on FFPE slides in tumours $(\mathrm{N}=37)$ and in the corresponding surgical margin sample. MMP-7 serum level was measured preoperatively. The expression of MMP-7 in cancer tissue was much stronger as compared to the normal intestinal mucosa. Also the level of MMP-7 in the serum of CRC patients was higher than in healthy subjects $(\mathrm{N}=24)(p<0.01)$. The tumour located in the colon showed higher expression of MMP-7 than CRCs located in the rectum $(p<0.05)$, whereas the higher MMP-7 serum level showed correlation with older age $(p=0.005)$, tumour size less than $5 \mathrm{~cm}(p<0.05)$, higher Dukes' stage $(p<0.05)$ and distant metastases $(p<0.05)$. The increased serum level of MMP-7 in CRC patients may indicate the presence of distant metastases. (Folia Histochemica et Cytobiologica 2013, Vol. 51, No. 3, 206-212)
\end{abstract}

Key words: colorectal cancer, matrix metalloproteinase-7, metastasis, serum level, colon, rectum

\section{Introduction}

Colorectal cancer (CRC) is the third most common malignancy worldwide in men and women [1]. Poland belongs to Central European countries with moderate morbidity rates, $\mathrm{CRC}$ is mainly a disease of developed Western countries [2]. CRC is the fourth leading cause of death, with prognosis indicating a growing trend [3]. The diagnosis is usually late and 5-year

Correspondence address: A. Pryczynicz, Department of General Pathomorphology, Medical University of Bialystok, Waszyngtona 13, 15-269 Bialystok, Poland; tel.: +48 8574859 96; fax: +48 8574859 96; e-mail: pryczynicz.anna@gmail.com survival rate ranges from $90 \%$ for early cancers, $70 \%$ for regional, to $10 \%$ for distant metastatic cancers. Therefore, there are studies for new and effective markers that could detect CRC and for therapeutic purposes [4].

Carcinogenesis in the large intestine is a complex, multi-stage process leading to excessive tissue proliferation that cannot be controlled by natural mechanisms due to predominance of cell proliferation over cell death. However, local neoplastic growth would not be possible without reconstruction of the extracellular matrix (ECM). Stromal degradation and looseness also allow migration of cancer cells and thus their dissemination, vascular invasion and formation of distant metastases. The reconstruction of the ECM involves a variety of digestive enzymes $[5,6]$. However, a major role can be ascribed to me- 
talloproteinases, which are intensively investigated in carcinogenic processes.

One of the most important metalloproteinases is MMP-7 due to its low molecular mass $(28 \mathrm{kDa})$ and unique structure; it is also called matrilysin- 1 or PUMP-1 [7]. Physiologically, MMP-7 is found in ductal and glandular epithelium of many tissues, also in monocytes or mesangial cells [8-11]. On the other hand, its overexpression has been detected in various neoplastic lesions, including lung, prostate, stomach and colon cancer [12-15]. Active matrilysin-1 shows a proteolytic activity on the ECM components, such as collagen, elastin, laminin, proteoglycans, fibronectin and casein [9]. It is also able to activate other metalloproteinases (MMP-2 and MMP-9) affecting the ECM, which promotes invasion of cancer cells [16-18]. Apart from the digestion of the stroma, MMP-7 also takes part in other processes involved in the carcinogenesis through breakdown of the cell surface protein [19]. In this way, the enzyme can induce proliferation [19-21], and regulate apoptosis [22, 23], angiogenesis [24] and escape of cancer cells against the immune system [25].

The knowledge of the mechanisms that regulate carcinogenesis could help to predict the advancement of neoplastic disease and, eventually, inhibit its progression. Therefore, we decided to detect the presence of MMP-7 in cancer tissue in correlation with its serum level in CRC patients and to analyse this protein as a potential marker in clinical practice.

\section{Material and methods}

Patients. The study was carried out on a group of 45 patients with CRC ( 30 men and 15 women aged $34-86$ years, mean $66.8 \pm 11.8$, median 66) treated in the 2nd Department of General and Gastroenterological Surgery, Medical University of Bialystok, Poland, in the years 2007-2009. Colorectal cancers were diagnosed histopathologically as the adenocarcinoma type without the mucinous component in $40 / 45$ patients and as the mucinous type in $5 / 45$ patients. Histologically, the tumours were identified as moderately(42/45 patients) or poorly-differentiated carcinomas (3/45 patients). According to TNM classification, in one case tumour infiltration was limited to the submucosa (pT1), in 4 cases the muscular layer was invaded (pT2) and in as many as 40 cases the subserosa was involved (pT3). In 25/45 patients, there was local lymph node involvement and in 18/45 distant metastases were found, mainly in the liver, pancreas, lungs, kidneys, ovaries and uterine body. The surgical interventions were not preceded by chemotherapy or radiotherapy.

The blood $(5 \mathrm{~mL})$ of 45 colorectal cancer patients was drawn for clot prior to surgery. Blood serum was stored frozen at $-80^{\circ} \mathrm{C}$ immediately after separation by centrifugation until the assay was performed.
The control group consisted of 24 healthy subjects (13 men and 11 women aged 45-75 years, mean $55.7 \pm 7.3$, median 54.5). The blood was collected from control patients before colorectal cancer screening test - colonoscopy.

The study was approved by the local Bioethics Committee. Each patient gave written informed consent for participation in the study.

Immunohistochemistry. The expression of MMP-7 protein was determined in cancer tissue and normal tissue of the surgical margin of CRC patients (glandular and surface epithelium) by immunohistochemistry. The tissue material was obtained only from 37 patients. The study used archival material consisting of paraffin-embedded colorectal cancer tissues. The control group included samples of healthy mucosa of the colon, collected from the resected unchanged intestinal fragments of the same patients $(\mathrm{N}=37)$. Formalin-fixed and paraffin-embedded tissue specimens were cut with a microtome into $4 \mu \mathrm{m}$ sections and mounted on silinized glass slides. The sections were deparaffinized in xylene and hydrated in alcohols. The antigen retrieval was not performed. Endogenous peroxidase was blocked with $3 \%$ hydrogen peroxide for $10 \mathrm{~min}$. Protein blocking was done with a serum-free protein blocker (Novocastra, UK) to reduce non-specific binding of primary and secondary antibodies. Next, they were incubated with murine monoclonal anti-human MMP-7 antibody (clone: 111433, R\&D Systems, UK) in 1:500 dilution for $60 \mathrm{~min}$. at room temperature. The primary antibody was specific for human pro- and active forms of MMP-7. The streptavidin-biotin reaction (Biotinylated Secondary Antibody, Streptavidin-HRP, Novocastra, UK) was followed according to manufacturer's protocol by visualization of the antigen-antibody complex using chromogen 3,3-diaminobenzidine (DAB, Novocastra, UK). Nuclei were counterstained with hematoxylin.

Positive reaction for MMP-7 was observed in the cytoplasm of normal mucosa and in cancer cells. Positive and negative controls were performed according to the producer's protocol (Novocastra, UK).

The expression of MMP-7 protein was assessed semiquantitatively based on staining intensity, which was defined depending on visualization of the reaction at the respective microscopic magnifications. The expression was defined as strong when the reaction was visible at $\times 40$ total magnification, moderate - at $\times 100$, poor - at $\times 200$, lacking - when not visible at $\times 200$. Since there were only 4 cases with lacking or poor reaction, they were treated as one group for statistical purposes.

Enzyme-linked immunoabsorbent assays (ELISA). MMP-7 concentration was measured with a quantitative sandwich enzyme immunoassay (Human Total MMP-7 Quantikine ELISA Kit, R\&D Systems, UK) according to the manufacturer's protocol. The serum samples were diluted 2-fold. All 


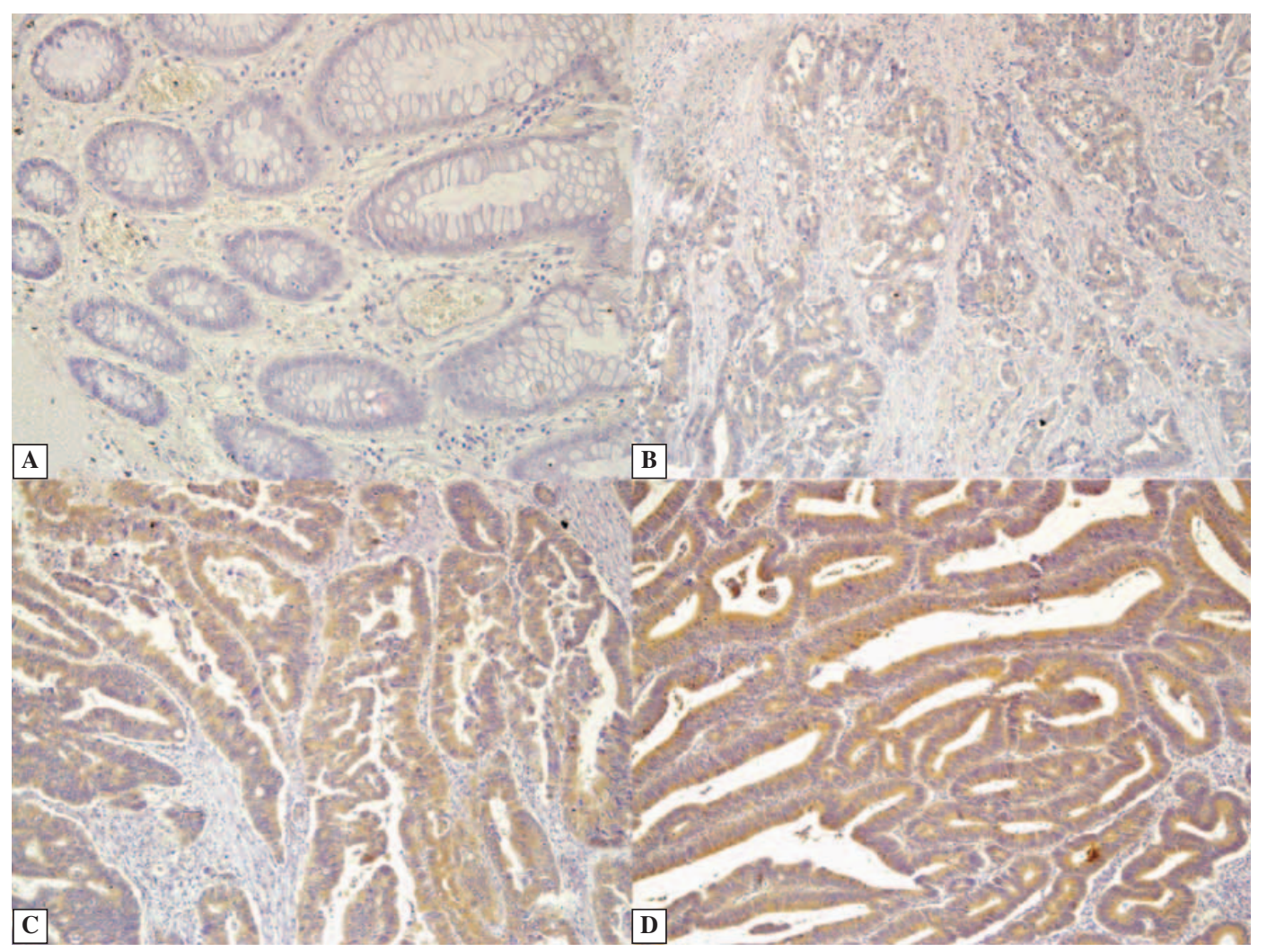

Figure 1. Immunohistochemical expression of MMP-7. A. lack of expression of MMP-7 in normal mucosa $(\times 20)$; B. poor $(\times 20)$; C. moderate $(\times 40)$ and $\mathbf{D}$. strong expression of MMP-7 in colorectal cancer cells $(\times 40)$

the specimens were assayed twice in duplicate. The MMP-7 Quantikine ELISA kit detected both pro- and active forms of recombinant and normal human MMP-7. The results were presented in nanograms per millilitre.

Statistics. Statistical analysis was based on STATISTICA 8.0 program (Statsoft, Cracow, Poland). Statistical analysis was conducted using Student's $t$-test. The data distribution was normal according to Shapiro-Wilk $W$-test. The Mann-Whitney $U$-test was used to compare the two groups. Spearman's correlation coefficient test was applied to find correlations of serum protein level with clinicopathological factors and morphological parameters of blood. The value of $p<0.05$ was considered statistically significant. Missing data were removed in pairs. Additionally, the area under the ROC curve (AUC) was assessed using MedCalc statistical software (MedCalc Software, Ostend, Belgium).

\section{Results \\ Immunohistochemical expression of MMP-7 in colorectal cancer}

In normal mucosa membrane of the resected fragment of the large intestine, the expression of MMP-7 was either lacking or poor to moderate, and irregularly distributed in glands (Figure $1 \mathrm{~A}$ ). In the colorectal cancer samples, the positive reaction was observed in the cytoplasm of cancer cells and identified as negative or poor in 4 patients, moderate in 18 and strong in 15 cases (Figure $1 \mathrm{~B}, \mathrm{C}, \mathrm{D}$ ). The statistical analysis showed no significant correlations of MMP-7 expression in cancer tissue with gender and age of patients, tumour grade, tumour stage (pT), Dukes' classification, lymph node involvement or distant metastases. A statistically significant correlation was found between tumour location in the colon and high expression of MMP-7 in cancer tissue. In rectal cancers, moderate expression of MMP-7 was predominant $(p<0.05$; $r=-0.355)($ Table 1).

\section{Serum MMP-7 levels of colorectal cancer and con- trol patients}

The serum concentration of MMP-7 in colorectal cancer patients ranged between 4.32 and $12.93 \mathrm{ng} / \mathrm{mL}$ $(7.45 \pm 1.88 \mathrm{ng} / \mathrm{mL}$, mean and $\mathrm{SD} ; \mathrm{N}=45)$, and was significantly higher than in healthy subjects $(6.31 \pm$ $\pm 0.91 \mathrm{ng} / \mathrm{mL}$, range 4.94-8.26, $\mathrm{N}=24)(p<0.01)$. The ROC curve showed that the cut-off point for MMP-7 was at the level of $6.88 \mathrm{ng} / \mathrm{mL}$ (sensitivity $58.3 \%$ and specificity $87.5 \%$ ). The area under the ROC curve for MMP-7 level was 0.710, which indicates mode- 
Table 1. Correlations between imunohistochemical expression of MMP-7 in tumour tissue and clinicopathological parameters in colorectal cancer patients

\begin{tabular}{|c|c|c|c|c|c|}
\hline \multicolumn{2}{|l|}{ Parameter } & \multicolumn{4}{|c|}{$\begin{array}{l}\text { MMP-7 expression in tumour } \\
\text { (Number of patients, percentage) }\end{array}$} \\
\hline & & \multirow{2}{*}{$\begin{array}{c}\text { Absent/poor } \\
0(0 \%) \\
4(16 \%) \\
\end{array}$} & \multirow{2}{*}{$\begin{array}{c}\text { Medium } \\
8(66.7 \%) \\
10(40 \%) \\
\end{array}$} & \multirow{2}{*}{$\begin{array}{c}\text { Strong } \\
4(33.3 \%) \\
11(44 \%) \\
\end{array}$} & \multirow{2}{*}{$\frac{p \text { value }}{\text { NS }}$} \\
\hline Age & $\begin{array}{l}<60 \\
\geq 60\end{array}$ & & & & \\
\hline Gender & $\begin{array}{l}\text { Male } \\
\text { Female }\end{array}$ & $\begin{array}{c}4(16.7 \%) \\
0(0 \%)\end{array}$ & $\begin{array}{l}12(50 \%) \\
6(46.1 \%)\end{array}$ & $\begin{array}{l}8(33.3 \%) \\
7(53.9 \%)\end{array}$ & NS \\
\hline Localization & $\begin{array}{l}\text { Colon } \\
\text { Rectum }\end{array}$ & $\begin{array}{c}1(4.3 \%) \\
3(21.4 \%)\end{array}$ & $\begin{array}{l}10(43.5 \%) \\
8(57.2 \%)\end{array}$ & $\begin{array}{l}12(52.2 \%) \\
3(21.4 \%)\end{array}$ & $\begin{array}{l}p<0.05 \\
\mathrm{r}=-0.355\end{array}$ \\
\hline Adenocarcinoma type & $\begin{array}{l}\text { Non-mucinous } \\
\text { Mucinous }\end{array}$ & $\begin{array}{c}4(11.8 \%) \\
0(0 \%)\end{array}$ & $\begin{array}{l}16(47.1 \%) \\
2(66.7 \%)\end{array}$ & $\begin{array}{c}14(41.1 \%) \\
1(33.3 \%)\end{array}$ & NS \\
\hline Grade of malignancies & $\begin{array}{l}2 \\
3 \\
\end{array}$ & $\begin{array}{c}4(11.4 \%) \\
0(0 \%)\end{array}$ & $\begin{array}{c}17(48.6 \%) \\
1(50 \%)\end{array}$ & $\begin{array}{c}14(40 \%) \\
1(50 \%)\end{array}$ & NS \\
\hline Tumour size & $\begin{array}{l}<5 \mathrm{~cm} \\
\geq 5 \mathrm{~cm}\end{array}$ & $\begin{array}{l}2(9.5 \%) \\
2(12.5 \%)\end{array}$ & $\begin{array}{c}8(38.1 \%) \\
10(62.5 \%)\end{array}$ & $\begin{array}{c}11(52.4 \%) \\
4(25 \%)\end{array}$ & NS \\
\hline pT stage & $\begin{array}{l}1 \\
2 \\
3 \\
\end{array}$ & $\begin{array}{c}0(0 \%) \\
0(0 \%) \\
4(12.6 \%)\end{array}$ & $\begin{array}{c}1(100 \%) \\
3(75 \%) \\
14(43.7 \%)\end{array}$ & $\begin{array}{c}0(0 \%) \\
1(25 \%) \\
14(43.7 \%)\end{array}$ & NS \\
\hline Duke stage & $\begin{array}{l}\mathrm{A} \\
\mathrm{B} \\
\mathrm{C} \\
\mathrm{D}\end{array}$ & $\begin{array}{c}0(0 \%) \\
2(20 \%) \\
0(0 \%) \\
2(14.4 \%)\end{array}$ & $\begin{array}{c}2(100 \%) \\
4(40 \%) \\
6(54.5 \%) \\
6(42.8 \%) \\
\end{array}$ & $\begin{array}{c}0(0 \%) \\
4(40 \%) \\
5(45.5 \%) \\
6(42.8 \%) \\
\end{array}$ & NS \\
\hline Lymph node metastases & $\begin{array}{l}\text { Absent } \\
\text { Present }\end{array}$ & $\begin{array}{c}3(18.75 \%) \\
1(4.8 \%) \\
\end{array}$ & $\begin{array}{c}8(50 \%) \\
10(47.6 \%)\end{array}$ & $\begin{array}{l}5(31.25 \%) \\
10(47.6 \%)\end{array}$ & NS \\
\hline Distant metastases & $\begin{array}{l}\text { Absent } \\
\text { Present }\end{array}$ & $\begin{array}{l}2(8.7 \%) \\
2(14.4 \%)\end{array}$ & $\begin{array}{c}12(52.2 \%) \\
6(42.8 \%)\end{array}$ & $\begin{array}{l}9(39.1 \%) \\
6(42.8 \%)\end{array}$ & NS \\
\hline
\end{tabular}

The immunoreactivity was assessed as described in Methods. Pearson's correlation coefficient test. Missing data were removed in pairs. NS — non significant

rate diagnostic potential of the test in CRC patients (Figure 2).

\section{Correlations between serum MMP-7 levels and clinicopathological parameters in colorectal cancer patients}

The serum level of MMP-7 in CRC patients over 60 years of age (mean $73.2 \pm 7.4$, median 74 ) was significantly higher than in the group of younger patients $(>60$ years old, mean $52.9 \pm 6.2$, median 54) (Table 2). Tumours $>5 \mathrm{~cm}$ in diameter were found to correlate with lower serum concentration of MMP-7, whereas those $<5 \mathrm{~cm}$ in diameter had higher matrilysin-1 level (Table 2). Moreover, the increased level of MMP-7 correlated with higher stage in Duke's classification (Table 2). A positive correlation was also observed between the presence of distant metastases and higher serum MMP-7 level in CRC patients (Table 2). No statistically significant differences were noted between the serum level of MMP-7 and other clinicopathological parameters.

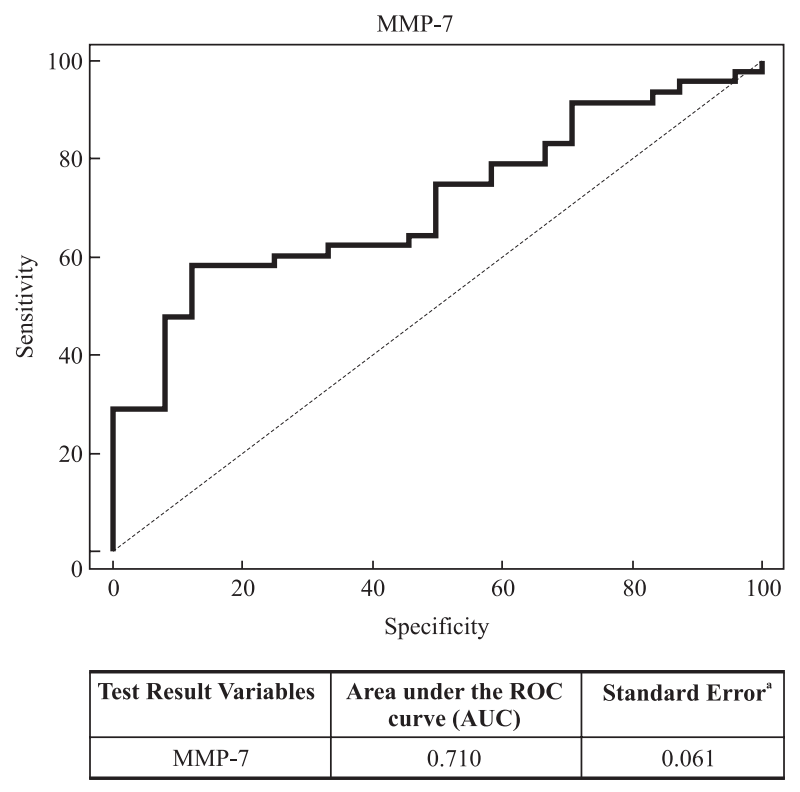

Figure 2. Area under the ROC curves for MMP-7 serum levels in differentiation between colorectal cancer patients and healthy subjects 
Table 2. Correlations between serum MMP-7 concentration and clinicopathological parameters in colorectal cancer patients

\begin{tabular}{|c|c|c|c|c|c|c|}
\hline \multirow[t]{2}{*}{ Parameter } & & \multicolumn{5}{|c|}{ MMP-7 [ng/mL] } \\
\hline & & $\mathbf{N}$ & Mean & Range & Coefficient & $p$ value \\
\hline Age & $\begin{array}{l}\leq 60 \\
>60\end{array}$ & $\begin{array}{l}15 \\
30\end{array}$ & $\begin{array}{l}6.58 \\
7.88\end{array}$ & $\begin{array}{l}4.99-11.77 \\
4.32-12.93\end{array}$ & 0.417 & $<0.01$ \\
\hline Gender & $\begin{array}{l}\text { Male } \\
\text { Female }\end{array}$ & $\begin{array}{l}28 \\
17\end{array}$ & $\begin{array}{l}7.16 \\
7.92\end{array}$ & $\begin{array}{l}4.32-11.77 \\
5.20-12.93\end{array}$ & -0.146 & NS \\
\hline Localization & $\begin{array}{l}\text { Colon } \\
\text { Rectum }\end{array}$ & $\begin{array}{l}26 \\
19\end{array}$ & $\begin{array}{l}7.41 \\
7.50\end{array}$ & $\begin{array}{l}4.32-12.93 \\
4.99-11.77\end{array}$ & 0.032 & NS \\
\hline Adenocarcinoma type & $\begin{array}{l}\text { Nonmucinous } \\
\text { Mucinous }\end{array}$ & $\begin{array}{c}40 \\
5\end{array}$ & $\begin{array}{l}7.53 \\
6.80\end{array}$ & $\begin{array}{c}4.99-12.93 \\
4.32-9.06\end{array}$ & -0.098 & NS \\
\hline Grade of malignancies & $\begin{array}{l}2 \\
3\end{array}$ & $\begin{array}{c}42 \\
3\end{array}$ & $\begin{array}{l}7.46 \\
7.25\end{array}$ & $\begin{array}{c}4.32-12.93 \\
6.12-8.15\end{array}$ & 0.000 & NS \\
\hline Tumour size & $\begin{array}{l}<5 \mathrm{~cm} \\
\geq 5 \mathrm{~cm}\end{array}$ & $\begin{array}{l}26 \\
17\end{array}$ & $\begin{array}{l}7.84 \\
6.80\end{array}$ & $\begin{array}{l}5.36-11.77 \\
4.32-12.93\end{array}$ & -0.308 & $<0.05$ \\
\hline pT stage & $\begin{array}{l}1 \\
2 \\
3\end{array}$ & $\begin{array}{c}1 \\
4 \\
40\end{array}$ & $\begin{array}{l}5.52 \\
7.13 \\
7.53\end{array}$ & $\begin{array}{c}5.52 \\
5.71-10.76 \\
4.32-12.93\end{array}$ & 0.217 & NS \\
\hline Duke stage & $\begin{array}{l}\text { A } \\
\text { B } \\
\text { C } \\
\text { D }\end{array}$ & $\begin{array}{c}2 \\
13 \\
12 \\
18\end{array}$ & $\begin{array}{l}5.68 \\
6.95 \\
7.20 \\
8.17\end{array}$ & $\begin{array}{c}5.52-5.85 \\
4.32-9.06 \\
4.99-10.76 \\
5.71-12.93\end{array}$ & -0.324 & $<0.05$ \\
\hline Lymph node metastases & $\begin{array}{l}\text { Absent } \\
\text { Present }\end{array}$ & $\begin{array}{l}20 \\
25\end{array}$ & $\begin{array}{l}6.82 \\
7.95\end{array}$ & $\begin{array}{c}4.32-9.06 \\
4.99-12.93\end{array}$ & 0.246 & NS \\
\hline Distant metastases & $\begin{array}{l}\text { Absent } \\
\text { Present }\end{array}$ & $\begin{array}{l}27 \\
18\end{array}$ & $\begin{array}{l}6.97 \\
7.95\end{array}$ & $\begin{array}{l}4.32-10.76 \\
4.99-12.93\end{array}$ & 0.312 & $<0.05$ \\
\hline IHC expression of MMP-7 & $\begin{array}{l}\text { Poor } \\
\text { Medium } \\
\text { Strong }\end{array}$ & $\begin{array}{c}4 \\
18 \\
15\end{array}$ & $\begin{array}{l}8.29 \\
6.86 \\
7.86\end{array}$ & $\begin{array}{c}8.20-8.48 \\
4.32-12.93 \\
5.35-10.76\end{array}$ & 0.199 & NS \\
\hline
\end{tabular}

Correlation coefficients were calculated by using Spearman's correlation test. Missing data were removed in pairs. NS - not statistically significant.

Also immunohistochemical expression of MMP-7 in cancer tissue did not correlate with its serum level in CRC patients (Table 2).

\section{Correlations between serum MMP-7 levels and blood morphology parameters in colorectal cancer patients}

The statistical analysis revealed a negative correlation between serum level of MMP-7 and serum glucose concentration in CRC patients $(p<0.01)$ (Table 3$)$. However, any significant correlation was found between serum MMP-7 concentration and other parameters.

\section{Discussion}

The current study confirmed the observations of other authors that MMP-7 expression in colorectal cancer tissues is markedly higher than in normal intestinal mucosa, which proves the involvement of this metallo- proteinase in CRC growth [26-30]. Also the finding of enhanced MMP-7 mRNA confirmed the involvement $[11,31,32]$. The statistical analysis showed only a stronger relationship of MMP-7 overexpression with tumours located in the colon as compared to those in the rectum. However, we revealed no significant correlations between MMP-7 expression in tumour cells and CRC advancement, similarly to Gomes et al. [26], who used antibody that detected both pro- and active forms of MMP-7. However, investigations done by Wang et al. [33] proved the correlation of positive MMP-7 expression with tumour infiltration depth in the intestinal wall and with distant metastases. Ogawa et al. [34] noted that MMP-7 expression in lymphatic vessels is a useful parameter in predicting CRC metastases to the liver. They also showed that the assessment of matrilysin expression can help prognosticate the course of the disease. Koskensalo et al. [28] revealed a link between high MMP-7 reaction in cancer and worse prognosis during a 5-year follow-up. Also research data on mRNA MMP-7 expression are 
Table 3. Correlation between serum MMP-7 levels and blood morphology parameters in CRC patients

\begin{tabular}{|l|c|c|c|}
\hline \multirow{2}{*}{ Parameter } & \multicolumn{3}{|c|}{ MMP-7 } \\
\cline { 2 - 4 } & N & Coefficient & p value \\
\hline Red Blood Cell Count & 33 & -0.272 & NS \\
\hline White Blood Cell Count & 33 & 0.042 & NS \\
\hline PLT & 33 & -0.024 & NS \\
\hline Haematocrit & 33 & -0.243 & NS \\
\hline Haemoglobin & 33 & -0.228 & NS \\
\hline Sodium & 33 & -0.307 & NS \\
\hline Potassium & 33 & 0.054 & NS \\
\hline Prothrombin time & 32 & -0.083 & NS \\
\hline Prothrombin index & 30 & 0.070 & NS \\
\hline Total proteins & 22 & -0.285 & NS \\
\hline Albumins & 20 & -0.088 & NS \\
\hline Aspartate Transaminase & 24 & 0.334 & NS \\
\hline Alanine Transaminase & 24 & 0.250 & NS \\
\hline Glucose & 17 & -0.610 & $<0.01$ \\
\hline Urea & 29 & 0.345 & NS \\
\hline Creatinine & 26 & -0.059 & NS \\
\hline
\end{tabular}

NS; Spearman's correlation coefficient test. Missing data were removed in pairs. NS - not statistically significant

in favour of this metalloproteinase as a biological marker of CRC aggression. RT-PCR investigations by Mori et al. [31] and Wan et al. [35] found a correlation of MMP-7 mRNA overexpression with advanced Dukes' stage and the presence of metastases to the liver.

Our immunohistochemical findings do not seem to indicate that MMP-7 is a CRC stage marker. However, according to the results, the assessment of its preoperative serum level can be such a marker. We demonstrated a correlation of the increased serum level of MMP-7 with higher Dukes' stage and with distant metastases. Also Maurel et al. [36] observed elevated serum levels of MMP-7 in patients with advanced CRC as compared to non-metastatic CRC. Moreover, they showed MMP-7 to be an independent prognostic factor for survival in patients with advanced CRC. On the other hand, Martinez-Fernandez et al. [37], found not only the correlation between increased serum level of MMP-7 and worse prognosis, but also revealed that MMP-7 predicts recurrence in curatively resected CRC patients. Additionally, similarly to our observations, they noted high serum level of MMP-7 in older CRC patients.

We divided the study group of colorectal cancers into $<5 \mathrm{~cm}$ and $>5 \mathrm{~cm}$ tumours. Interestingly, we observed a correlation between the increased serum level of MMP-7 in CRC patients and tumours $<5 \mathrm{~cm}$ in diameter. However, literature data do not confirm this correlation.

We also examined correlations between serum levels of MMP-7 in CRC patients with other blood parameters. In our study, a rise in the level of MMP-7 was associated with decreased blood glucose levels. Maurel et al. [36] showed a relationship between high serum level of MMP-7 in CRC patients and elevated parameters, such as LDH, ALP and CEA. Perhaps, MMP-7 affects these factors through involvement in some unknown mechanisms.

We observed increased expression and level of MMP-7 both in immunohistochemical investigations and in ELISA, as compared to the control group. Although we used the antibody detecting pro- and active forms of MMP-7 in both methods, we found no correlation between the immunohistochemical expression of MMP-7 in cancer tissue and its blood serum level in CRC patients. Perhaps, the ratio of pro- and active forms of MMP-7 differs between tissue and serum in CRC patients, one of them having prognostic advantage over the other. Future investigations using specific antibodies or assessment of MMP-7 activity with zymographic method might help elucidate this phenomenon. Nevertheless, MMP-7 should be considered as an important factor in the carcinogenic process, especially, as a marker of the disease advancement that can be determined with a simple noninvasive ELISA method. The current study seems to confirm and extend earlier analyses of other authors concerning MMP-7 expression in CRC, indicating possible use of MMP-7 as a prognostic marker of CRC.

\section{References}

1. World Health Organization Cancer Incidence in Five Continents. Lyon. The World Health Organization and The International Agency for Research on Cancer. 2002.

2. Boyle P, Langman JS. ABC of colorectal cancer: Epidemiology. BMJ. 2000;321:805-808.

3. Boyle P, Ferlay J. Mortality and survival in breast and colorectal cancer. Nat Clin Pract Oncol. 2005;2:424-425.

4. Jemal A, Clegg L X, Ward E et al. Annual report to the nation on the status of cancer, 1975-2001, with a special feature regarding survival. Cancer. 2004;101:3-27.

5. Hua H, Li M, Luo T et al. Matrix metalloproteinases in tumorigenesis: an evolving paradigm. Cell Mol Life Sci. 2011;68:3853-3868.

6. Friedl P, Wolf K. Tube travel: the role of proteases in individual and collective cancer cell invasion. Cancer Res. 2008;68:7247-7249.

7. Gaire M, Magbanua Z, McDonnell S et al. Structure and expression of the human gene for the matrix metalloproteinase matrilysin. J Biol Chem. 1994;269:2032-2040.

8. Harrell PC, McCawley LJ, Fingleton B et al. Proliferative effects of apical, but not basal, matrix metalloproteinase-7 activity in polarized MDCK cells. Exp Cell Res. 2005;303:308-320. 
9. Woessner JF Jr, Taplin CJ. Purification and properties of a small latent matrix metalloproteinase of the rat uterus. J Biol Chem. 1988;263:16918-16925.

10. Wilson CL, Matrisian LM. Matrilysin: an epithelial matrix metalloproteinase with potentially novel functions. Int $J$ Biochem Cell Biol. 1996;28:123-136.

11. McDonnell S, Navre M, Coffey RJ Jr et al. Expression and localization of the matrix metalloproteinase pump-1 (MMP7) in human gastric and colon carcinomas. Mol Carcinog. 1991;4:527-533.

12. Stenvold H, Donnem T, Andersen S et al. Overexpression of matrix metalloproteinase-7 and -9 in NSCLC tumor and stromal cells: correlation with a favorable clinical outcome. Lung Cancer. 2012;75:235-241.

13. Zhou JH, Zhang B, Kernstine KH et al. Autoantibodies against MMP-7 as a novel diagnostic biomarker in esophageal squamous cell carcinoma. World J Gastroenterol. 2011;17:1373-1378.

14. Koskensalo S, Mrena J, Wiksten JP et al. MMP-7 overexpression is an independent prognostic marker in gastric cancer. Tumour Biol. 2010;31:149-155.

15. Masaki T, Matsuoka H, Sugiyama M et al. Matrilysin (MMP7) as a significant determinant of malignant potential of early invasive colorectal carcinomas. Br J Cancer. 2001;84:13171321.

16. Noë V, Fingleton B, Jacobs K et al. Release of an invasion promoter E-cadherin fragment by matrilysin and stromelysin-1. J Cell Sci. 2001;114:111-118.

17. Lynch CC, Hikosaka A, Acuff HB et al. MMP-7 promotes prostate cancer-induced osteolysis via the solubilization of RANKL. Cancer Cell. 2005;7:485-496.

18. von Bredow DC, Nagle RB, Bowden GT et al. Cleavage of beta 4 integrin by matrilysin. Exp Cell Res. 1997;236:341-345.

19. Yu WH, Woessner JF Jr, McNeish JD et al. CD44 anchors the assembly of matrilysin/MMP-7 with heparin-binding epidermal growth factor precursor and ErbB4 and regulates female reproductive organ remodeling. Genes Dev. 2002;16:307-323.

20. Miyamoto S, Yano K, Sugimoto S et al. Matrix metalloproteinase-7 facilitates insulin-like growth factor bioavailability through its proteinase activity on insulin-like growth factor binding protein 3. Cancer Res. 2004;64:665-671.

21. Hemers E, Duval C, McCaig C et al. Insulin-like growth factor binding protein-5 is a target of matrix metalloproteinase-7: implications for epithelial-mesenchymal signaling. Cancer Res. 2005;65:7363-7369.

22. Davies G, Jiang WG, Mason MD. Matrilysin mediates extracellular cleavage of E-cadherin from prostate cancer cells: a key mechanism in hepatocyte growth factor/scatter factor-induced cell-cell dissociation and in vitro invasion. Clin Cancer Res. 2001;7:3289-3297.

23. Mitsiades N, Yu WH, Poulaki V et al. Matrix metalloproteinase-7-mediated cleavage of Fas ligand protects tumor cells from chemotherapeutic drug cytotoxicity. Cancer Res. 2001;61:577-581.

24. Lin HC, Chang JH, Jain S et al. Matrilysin cleavage of corneal collagen type XVIII NC1 domain and generation of a $28-\mathrm{kDa}$ fragment. Invest Ophthalmol Vis Sci. 2001;42:2517-2524.

25. Li Q, Park PW, Wilson CL et al. Matrilysin shedding of syndecan-1 regulates chemokine mobilization and transepithelial efflux of neutrophils in acute lung injury. Cell. 2002;111:635-646.

26. Gomes EG, Jucá MJ, de Menezes HL et al. Correlation between the immunohistochemical expressions of MMP1, MMP-7 and VEGF and prognostic factors in colorectal adenocarcinoma. Acta Cir Bras. 2009;24:303-310.

27. Luo HZ, Xia XQ, Zhou ZG et al. Expression and clinical significance of matrilysin (MMP-7) in human rectal cancer. Sichuan Da Хие Хие Вао Yi Хие Ban. 2007;38:637-640.

28. Koskensalo S, Louhimo J, Nordling S et al. MMP-7 as a prognostic marker in colorectal cancer. Tumour Biol. 2011;32:259-264.

29. Masaki T, Sugiyama M, Matsuoka H et al. Matrix metalloproteinases may contribute compensationally to tumor invasion in T1 colorectal carcinomas. Anticancer Res. 2003;23:41694173.

30. Adachi Y, Yamamoto H, Itoh $\mathrm{F}$ et al. Contribution of matrilysin (MMP-7) to the metastatic pathway of human colorectal cancers. Gut. 1999;45:252-258.

31. Mori M, Barnard GF, Mimori K et al. Overexpression of matrix metalloproteinase-7 mRNA in human colon carcinomas. Cancer. 1995;75:1516-1519.

32. Pesta M, Holubec L Jr, Topolcan O et al. Quantitative estimation of matrix metalloproteinases 2 and 7 (MMP-2, MMP-7) and tissue inhibitors of matrix metalloproteinases 1 and 2 (TIMP-1, TIMP-2) in colorectal carcinoma tissue samples. Anticancer Res. 2005;25:3387-3391.

33. Wang WS, Chen PM, Wang HS et al. Matrix metalloproteinase-7 increases resistance to Fas-mediated apoptosis and is a poor prognostic factor of patients with colorectal carcinoma. Carcinogenesis. 2006;27:1113-1120.

34. Ogawa M, Ikeuchi $\mathrm{K}$, Watanabe $\mathrm{M}$ et al. Expression of matrix metalloproteinase 7, laminin and type IV collagen-associated liver metastasis in human colorectal cancer: immunohistochemical approach. Hepatogastroenterology. 2005;52:875-880.

35. Wan Y, Wei Q, Pan Y et al. Expression of matrix metalloproteinases and tissue inhibitor of metalloproteinases in colorectal neoplasm. Zhonghua Wai Ke Za Zhi. 2000;38:510-513.

36. Maurel J, Nadal C, Garcia-Albeniz X et al. Serum matrix metalloproteinase 7 levels identifies poor prognosis advanced colorectal cancer patients. Int J Cancer. 2007;121:1066-1071.

37. Martínez-Fernandez A, García-Albeniz X, Pineda E et al. Serum matrilysin levels predict outcome in curatively resected colorectal cancer patients. Ann Surg Oncol. 2009;16:1412-1420.

Submitted: 9 April, 2013

Accepted after reviews: 25 July, 2013 